\title{
SWEET TASTE OF CELL DEATH: ROLE OF CARBOHYDRATE RECOGNITION SYSTEMS
}

\author{
Rostyslav BILYY, Rostyslav STOIKA \\ Institute of Cell Biology, National Academy of Sciences of Ukraine, Lviv; \\ e-mail: r.bilyy@nas.gov.ua; stoika@cellbiol.lviv.ua
}

This paper describes a complicated way how the glycoepitops' alterations on a surface of dying cells allow investigators to decipher specific mechanisms underlying cell restructuring at apoptosis. These glycoepitops are important at removal of fragments of dying cells from the body, which can be a cause of formation of the auto-antibodies.

Ke y words: apoptosis, glicoepitops, plasma membrane, microvesicles, phagocytosis.

$\mathrm{T}$ he number of cellular and molecular markers of apoptosis described in cytoplasm, nucleus and mitochondria, is increasing yearly. However, up to recent time, plasma membrane (PM) markers stayed to be less studied [1], and only phosphatidylserine (PS) externalization has been well characterized in that compartment, and already proposed for application in biology studies and medical diagnostics [2]. It should be stressed that PM markers of apoptosis possess some important advantages compared to all other markers of this phenomenon, since they are better accessible to extra-cellular interactions without disturbing cell integrity. Since PM markers of apoptotic cells can be recognized by the phagocytic and neighboring epithelial cells, they are very important for efficient elimination of apoptotic cells from tissues and organs. Cell death was shown to be accompanied by time-dependent sequence of intracellular events, starting with a trigger signal and ending with a complete removal of dying cells by their neighbors and macrophages. It is discussed since when one can consider the cell "dead" or "apoptotic". The organism senses the dying cells by a change of their surface markers and by a release of particular intercellular molecules [3] also related to changes in plasma membrane. Thus, the PM-derived apoptosis markers seem to be the most "physiological" measure of whether the cell is alive, dying, or already dead (necrotic).

Recently, glycoproteins (GPs) integrated in the PM of apoptotic cells, were addressed by the investigators searching for novel cell surface markers of apoptosis. The carbohydrate moiety of plasma membrane GPs, unlike the DNA or proteins, does not need a specific matrix for its synthesis. Besides, unlike $3^{\prime} \rightarrow 5^{\prime}$ phospodiester bonds in DNA, or peptide bonds in proteins, two carbohydrate molecules can be joined together by eleven different bond combinations providing a huge number of possible oligosaccharides and much higher information potential that is perfectly described by H.-J. Gabius [4].

Carbohydrate binding proteins, the lectins, have demonstrated to be a powerful tool for recognizing different carbohydrate moieties. They were discovered over 100 years ago, and hundreds of lectins with various carbohydrate specificity and different functions were described in plants and animals $[5,6]$. A principal function of lectin-carbohydrate interaction is well expressed at the immune response [7, 8], including autoimmunity [9], and cell elimination from the organism [10]. It was hypothesized [11], that such interaction could be an evolutionary ancestor of the antibody-antigen interaction.

\section{A historical sketch [12]}

In 1972, Kerr et al. [13] firstly described a new biological that phenomenon named apoptosis or programmed cell death. Initially, apoptosis was mainly characterized by morphological changes in the cell, however, later, a set of specific biochemical events was discovered to take place at apoptosis. In 1985, Duvall et al. [14] found that N,N'-diacetyl chitobiose, NAcGlc, and NAcGal inhibited interaction of mouse macrophages with the apoptotic thymocytes, and lectin-like molecule was shown as a proper mediator of such interaction. Although the apoptotic and non-apoptotic cells did not differ in relative amount of exposed Gal, NAcGal, $\mathrm{NAcGlc}$ or NAcNeu, the lectin-binding sites were less abundant on the apoptotic cell surface [15]. In 1992, Dini and co-authors [16] showed that recognition of apoptotic hepatocytes in primary culture was mediated by the asialoglycoprotein receptor. Soon, Hall et al. [17] reported about the existence of two mechanisms of recognition of apoptotic neutrophils (PMNs) by the fibroblasts, first - via the vitronectin receptor involving the ingestion of apoptotic neutrophils by the macrophages, and second - via the mannose/fucose-specific lec- 
tin that is not responsible for phagocytosis of the apoptotic PMNs by the macrophages. The inhibition of adherence of apoptotic bodies to sinusoidal endothelial cells of liver was achieved by Gal/ NAcGal/Man [18], thus, suggesting presence of carbohydrate-specific receptors in such interaction, and cell clearance was shown to be enhanced by intereukin-1 in that cellular system. The inhibitory action of specific carbohydrates towards phagocytosis of the apoptotic human Kupffer cells was also demonstrated [19].

In 1992, Fadok et al. [2] detected that phosphatidyl-L-serine (PS) exposure on the apoptotic leukocytes is important for their recognition by the macrophages and further clearance by these immune cells. Soon, the ability to recognize PS was proposed to be a universal feature of macrophages, and the mechanism of translocation of this phospholipid from the inner to outer layer of plasma membrane was suggested [20-22]. That also permitted introducing Annexin V as PS-specific binding agent $[23,24]$. A key role of interaction of PS with cell recognizing systems was shown in modulating the immune response triggered by the dying cells $[25,26]$. Targeting this interaction was found to be effective in inducing immune response against tumor cells via immunization with autologous apoptotic tumor cells [27, 28].

In 1999, Rapoport and Le Pendu [29] addressed a question regarding changes in glycan determinants of plasma membrane. The results of analysis of six colon carcinoma cell lines have demonstrated that UV-induced apoptosis was accompanied by a decrease in binding 2,3-sialilspecific MAA (Maackia amurensis) lectin. It was shown that 4 of 6 studied carcinoma cell lines expressed relatively small number of PNA lectinbinding targets which were specific to desialylated glycoepitops, and gained high amount of those targets during apoptosis. An increase in binding of fucose-specific UEA-I (Ulex europaeus I) lectin to the apoptotic cells was also observed. That was accompanied by a decrease in $\alpha 1,2$-fucosyltranferase activity, while the activity of $\alpha 1,3$-fucosyltranferase was inhibited during the UV-induced apoptosis and it was increased 2.5-fold during apoptosis induced by the anti-Fas.

\section{Screening of plasma membrane glycoproteins}

In 2003, we [30] and another group of investigators [31] independently proposed a similar lectin-based approach for detecting apoptotic cells which demonstrated changes in GPs pattern of PM at apoptosis. For comparing an expression of PM glycoproteins in intact and apoptotic cells, we have used a big set of peroxidase- and fluores- cent dye (FITC)-labeled lectins. It was found that $\alpha$-D-mannose specific lectins from Pisum sativum (PSL), Polygonatum multiflorum rhizome, D-mannose-specific (PMRL), Galanthus nivalis (GNA), and Narcissus pseudonarcissus (NPL) were better bound to the apoptotic cells than to the intact cells. $\beta$-D-galactose specific lectins isolated from Ricinus communis (RCA) and Viscum album (VAA), were also better bound to the apoptotic cells [32]. At the same time, binding of $\alpha 2,3$-sialic-specific MAA-II lectin with the surface of apoptotic cells was decreased (demonstrated by Azuma et al. [33], Batisse et al. [34], as well as our group [35]). Similar apoptosis-related decrease in binding of $\alpha 2,6$ sialil-specific lectin SNA isolated from Sambucus nigra, was shown in U-937 cells [34], but not in Jurkat T-cells [33]. Herrmann's group [36] found that both apoptotic and necrotic dying cells were selectively bound by non-toxic lectins isolated from Griffonia simplificolia II (GSL II), UEA-I and NPL. Those investigators also showed that apoptosis was accompanied by a loss of resistance of PM against acid treatment, leading to an exposition of binding targets of $\alpha$-Man-specific NPL lectin on cell surface. Thus, level of cell staining with NPL can be a reliable marker of apoptosis, "at least as sensitive as Annexin V binding assay", with a correlation coefficient between two methods counted for $\mathrm{R}^{2}=0.7249$ [31].

To identify GPs whose expression was changed during apoptosis, we isolated PM fraction, and then carried out lectin-affinity chromatography and high resolution electrophoresis in a gradient PAAG. GPs were also separated into integral and peripheral ones by means of Triton-X114 assay and gradient PAGE, and then subjected to lectin-blotanalysis. It was found that the GPs of interest were both integral and peripheral components of PM. MALDI-TOF study [37] revealed that they could participate in cell signaling (specific G-protein beta-subunit-like protein) and apoptosis signaling pathways (article in preparation), as well as in cytoskeleton functioning (dynein heavy chain, microtubule-actin cross-linking factor, dystonin isoform $\beta$ ). The AMID protein (apoptosis-inducing factor (AIF)-like mitochondrion-associated inducer of death) was identified by the MALDI-TOF mass spectrometry as a protein isolated by Pisum sativum lectin-affinity chromatography from PM fraction of the apoptotic murine leukemia L1210 cells, and was lacking in the intact L1210 cells. The obtained results suggest its possible glycosylation that was further suggested by finding $\mathrm{N}$-glycosylation sequeon in the signal peptide of AMID protein (in silico), and by predicting trans-membrane localization of its $\mathrm{N}$-terminal part. By using monoclonal 
antibodies to AMID, we demonstrated an elevated expression of the AMID in human leukemia Jurkat T-cells after apoptosis induction. Immunocytochemical study suggested its association with cell PM at apoptosis [38].

\section{Altered glycosylation at apoptotic cell death}

The mechanism(s) of modification of the glycocalyx remain unclear. During apoptosis, the cells might change the glycosylation of de novo synthesized glycoconjugates. Alternatively, mature GP might get modified by glycosidases (e.g. sialidases) in situ. Secondly, internal membranes containing immature glycoproteins (GP) might be exposed.

To analyze the mechanisms modifying the glycocalyx, we blocked at several steps the regular synthesis pathway for N-glycans of GP and gangliosides. It was found that the inhibitors of transcription [actinomycin D], translation [cycloheximide], N-glycan synthesis in the ER [tunicamycin, 2-deoxy-D-glucose], and export from Golgi to PM [monensin] did not prevent an increased exposure of galactose/mannose and decreased exposure of sialic acid, as we showed earlier [39]. Thus de novo glycoprotein synthesis was excluded as a potential contributor to altered surface glycoprofile at apoptosis.

However, neuraminidase inhibitor DANA (2,3-dehydro-2-deoxy- $\mathrm{N}$-acetylneuraminic acid) prevented the phenomenon of altered glycoepitop redistribution at apoptosis via blocking both a decrease in sialic acid and increase in galactose-rich residues. These results suggest an involvement of sialidase enzymes in modification of cell surface.

Sialidases are enzymes that trim terminal sialic acids from a range of substrates, including the glycoconjugates of PM. Changes in the activity of all known human sialidases were shown during tumorigenesis [40], and the level of surface sialylation was shown to be tightly connected with tumor cell invasiveness and metastatic potential [40]. Sialylation level also determines the clearance of aged or virus-infected cells. Thus, detection of neuraminidase activity is of primary importance for clinical diagnostics, as well as life science research. The ubiquity of sialic acids, diversity of cellular and viral neuraminidases [41], the absence of specific antibodies make problematic a detection of neuraminidases. Most of available methods for neuraminidase activity detection are based on chemical essays. Unfortunately, all of them have 2 principal disadvantages: their sensitivity is rather low and they are designed for cellular extracts and can not be utilized for direct detection of enzymatic activity in specific cellular compartment [42].
We proposed utilizing fluorescent neuraminidase substrate, 4-MUNA (2'-(4-Methylumbelliferyl)- $\alpha$-D-N-acetylneuraminic acid) and developed a method that is based on using fluorescent and confocal microscopy. That solved both problems of sialidase detection described above, and both strong signal of the enzymatic activity and information on its intracellular cellular localization were obtained [43, 44]. Using this approach permitted demonstrating an increase in sialidase activity in apoptotic cells comparing to viable and primary necrotic cells.

Fluorometric assay for sialidase activity revealed its significant increase in the apoptotic cells, starting as early as 2 hours after the action of apoptosis-inducing agent, and this was true when we studied both cell lysates and cell suspensions. When cells were placed into a solution containing sialidase substrate, we were able to observe under the fluorescent microscope the fluorescence of cleaved sialidase substrate on cell surface (Fig. 1). Since the substrate or products of its hydrolysis were not membrane-permeable, we supposed that increased sialidase activity at apoptosis was localized on cell PM. That suggestion was further supported by the results of using RBC agglutination assay with PNA lectin agglutinating cells with desialylated residues [45]. Our experiments also demonstrated that upon permeabialization one can use the proposed approach to detect sialidase activity in the intracellular compartments also [44].

Confocal scanning microscopy, as well as DIC microscopy, allowed detecting sialidase activity and simultaneous detection of Annexin V-FITC and PI binding. Sialidase substrate (as it is quite soluble) accumulated with time both on the cell surface and in the medium, leading to an increased background staining (Fig. 1). Analysis of MFI of 3 groups of cells, $\mathrm{AnV}(-) / \mathrm{Pi}(-), \mathrm{AnV}(+) /$ $\mathrm{PI}(-)$ and $\mathrm{AnV}(+) / \mathrm{PI}(+)$, revealed that cleaved sialidase substrate was accumulated during the course of incubation in all cell groups, however, with different rate (Fig. 1). Sialidase activity in the apoptotic $(\mathrm{AnV}(+) / \mathrm{PI}(-))$ cells was significantly higher than in viable cells $(\mathrm{AnV}(-) / \mathrm{Pi}(-))$. Cell incubation with both sialidase substrate and sialidase inhibitor DANA (2,3-dehydro-2-deoxy- $\mathrm{N}$-acetylneuraminic acid) prevented an appearance of blue fluorescent signal in both the apoptotic and viable cells. We speculate that blue fluorescent signal observed in opened (PI-positive) cells, results from leakage of fluorescent intracellular compounds, probably of cytochromes, with similar fluorescence spectra. That was due to blue laser $(405 \mathrm{~nm})$ used in our and other commercially available confocal systems, since sialidase activity was not detected in primary 


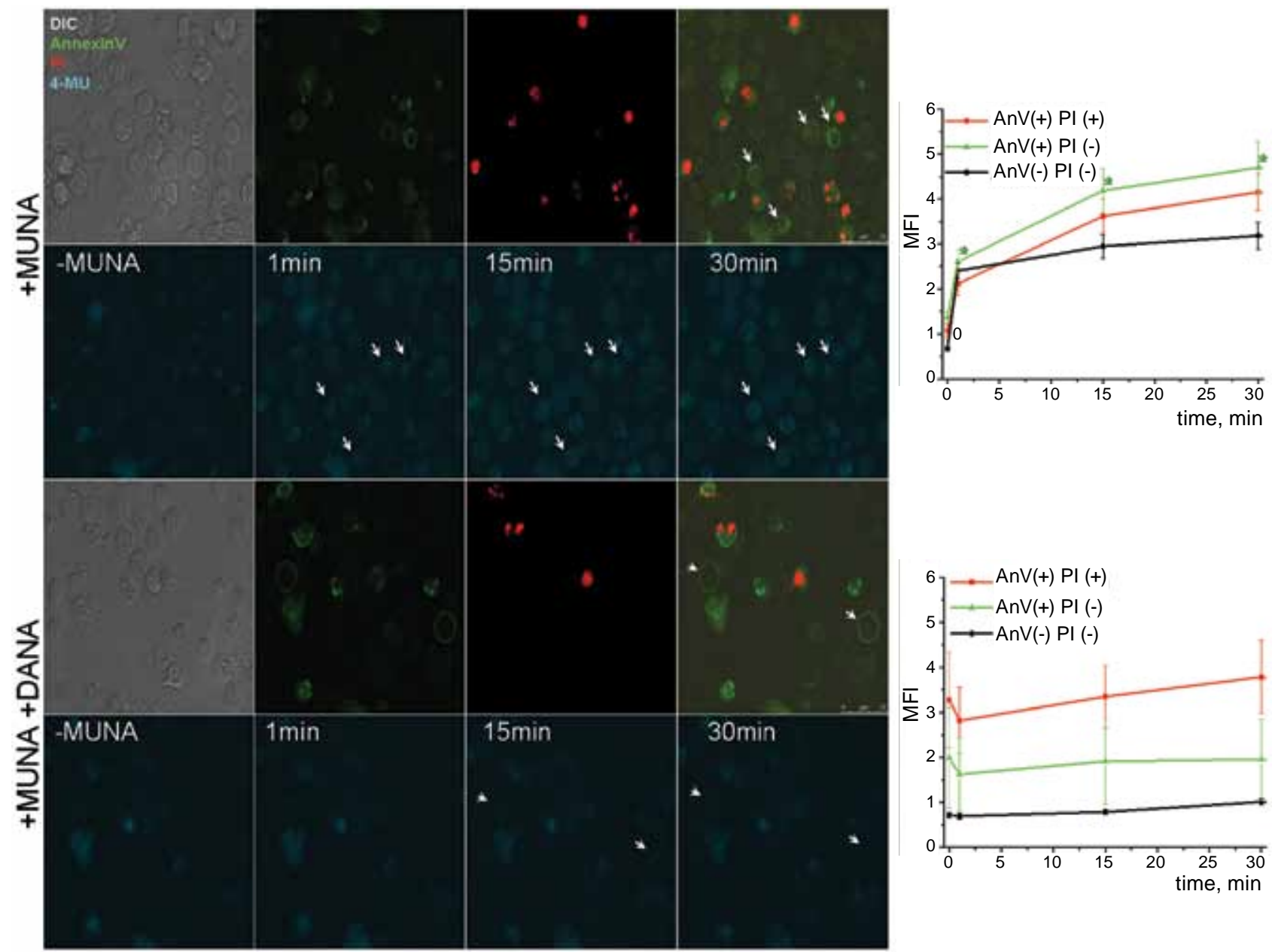

Fig. 1. Left: Accumulation of sialidase cleavage product (4-MU) in viable and dying human Jurkat T-cells, as revealed by the multi-channel confocal microscopy. Cells were counterstained with AnnexinV-FITC/PI. Upper rows - cleavage of sialidase substrate 4-MUNA, lower rows - sialidase inhibitor DANA prevented the appearance of cleavage product in the apoptotic cells. Right: MFI of blue fluorescent signal produced during cleavage of sialidase substrate 4-MU-NA in viable, apoptotic and necrotic cells, without (left) and with (right) addition of sialidase inhibitor. Apoptotic cells possessed an increased sialidase activity on their surface. Densitometry of confocal fluorescent images

necrotic cells (heated to $100{ }^{\circ} \mathrm{C}$ for $60 \mathrm{~s}$ ) when using fluorometric approach with excitation at 365 $\mathrm{nm}$. Besides, separation of PM fraction and its further separation into intra-membrane and peripheral proteins allowed localizing sialidase activity in the integral fraction of apoptotic PM.

Thus, both fluorescent and confocal microscopy allowed demonstrating that MUNA cleavage can be applied for detection of sialidase on cell surface. By using current approach, we proved an increase of sialidase activity on apoptotic $(\mathrm{AnV}+/$ PI-) but not necrotic (AnV+/PI+) or viable Jurkat T-cells.

Elevated sialidase activity in PM at apoptosis can explain an exposure of galactose residues on the surface of dying cell. At first, we supposed that the next set of enzymes, like galactosidases and $\mathrm{N}$-acethylglucosaminidase further trip typical $\mathrm{N}$-glycans of cell surface to expose oligomannoserich residues. However, soon we found that we were wrong, since testing of galactosidase activity with 4-MU-Gal (2'-(4-Methylumbelliferyl)- $\beta$-Dgalactoside) failed to detect any significant activity on both cell surface and in the conditioned media. On the contrary, an increased sialidase activity was detected on cell surface that rebutted the above noted hypothesis of sequential action of sialidases and galactosidases (Fig. 2). Thus, the origin of oligomannose residues on cell surface at apoptosis remained to be determined. 


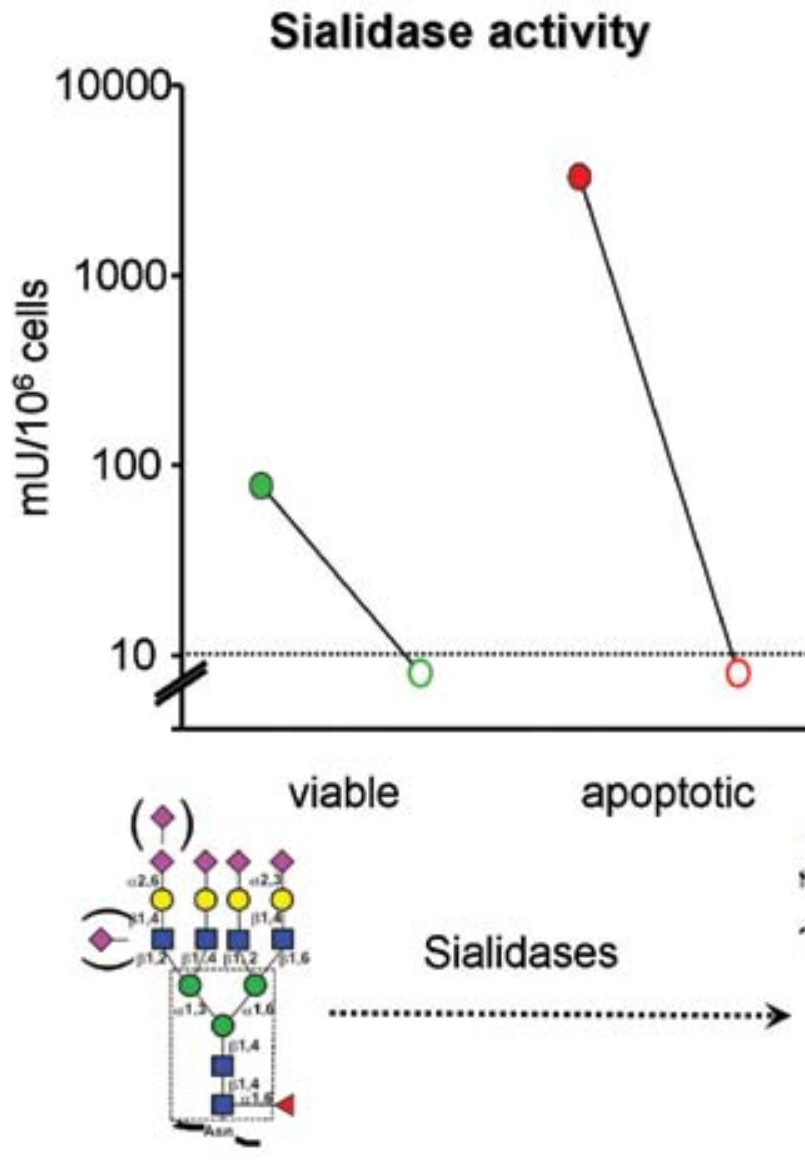

Glycans of viable cells
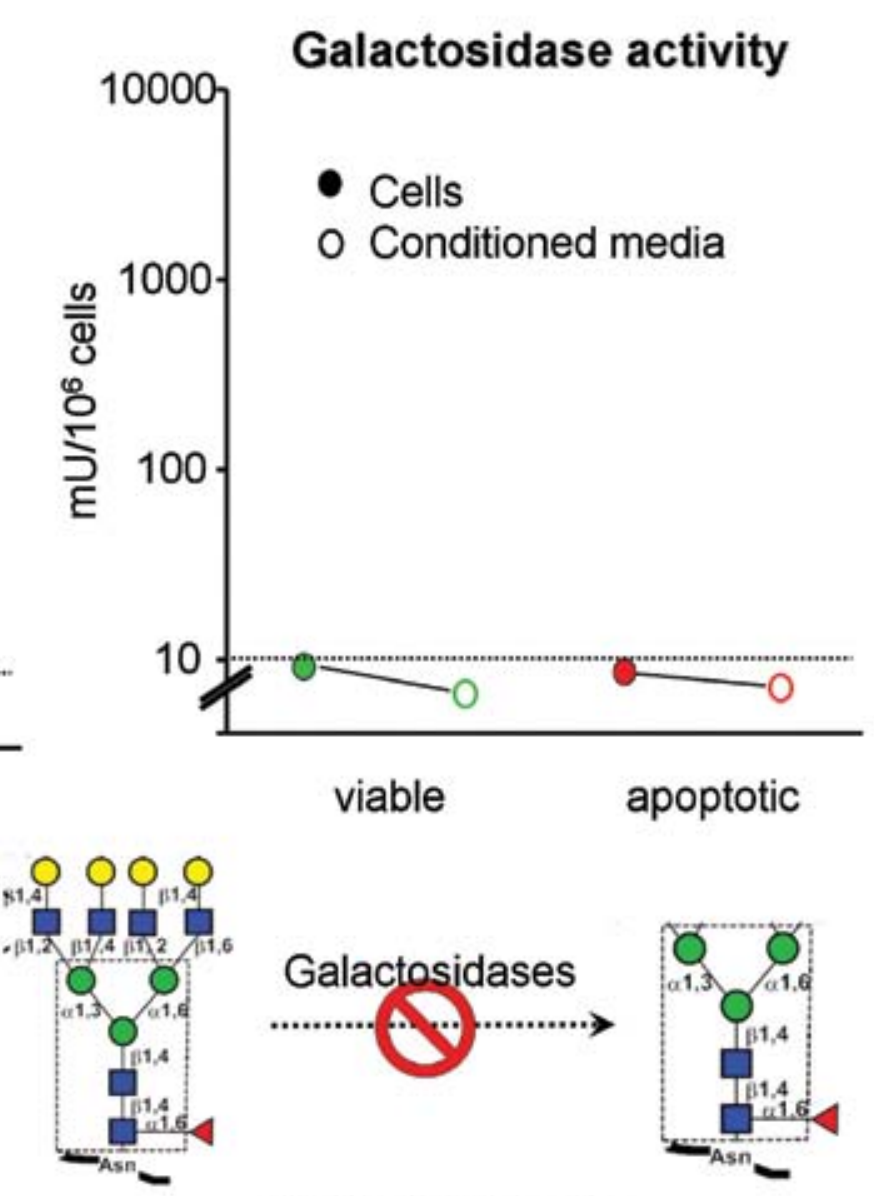

Apoptotic glycans

Fig. 2. Sialidases on surface of apoptotic cell (not secreted to intracellular medium) contribute to desialylation of dying cells and appearance of galactose residues, while galactosidase activity was not detected neither on surface of apoptotic cell, nor in cell incubation medium

\section{Glycosylation patterns of two} types of apoptotic blebs

Oligomannose residues in the form of N-glycan precursor are synthesized in ER of eukaryotic cell, then they are glucosylated (glucosylation serves as a retention signal for ER via binding with calnexin and calreticulin), transferred to the synthesized protein, deglucosylated, and finally, protein bearing $\mathrm{N}$-glycan with oligomannose residues is transferred to Golgi apparatus [46-50]. In 2007, Herrmann and collaborators reported about a possibility of exposure of ER resident proteins (calnexin, the KDEL receptor and a dysfunctional immunoglobulin heavy chain) and ER-associated ganglioside GM1 on the surface of shrunken apoptotic cell. These investigators suggested that during apoptosis, ER membrane is transported to cell surface in order to substitute PM that has been lost during membrane blebbing process (decreased sur- face/volume ratio) [51]. A possibility for ER components to bypass the Golgi complex during their transportation to PM was reported [52, 53], however, there is no information on whether ER-derived oligomannose-residues can be transferred directly to PM and on the course of this process at apoptosis.

We have started a joint project in collaboration with Prof. Herrmann's group aimed at elucidation of the ways of formation of the apoptotic blebs (here and after referred as ACMV - Apoptotic sub-Cellular Micro-Vesicles) at apoptosis, their glycol-content and immunological properties. We labeled cells' ER with ER-tracker (Invitrogen), induced apoptosis, and followed the carbohydrate content of the formed blebs, as well as their sialidase activity that was measured by the technique described above [43]. We have observed sialidase activity on both shrunken cell surface and PM-derived ACMV (negative for ER-tracker sig- 
nal) (Fig. 3A), and similar staining pattern was observed for VAA lectin specific to terminal galactose residues (Fig. 3B). Thus, PM components which were not bearing ER tags, possessed sialidase activity and exposed desialylated (galactoserich) glycoepitops. To the contrary, the ACMV arising from ER (positive for ER-tracker) were also positively stained with NPL lectin (Fig. 3C) specific to oligomannose $\mathrm{N}$-glycans and with CEL lectin (Fig. 3D) specific to glucosylated oligomannose $\mathrm{N}$-glycans (present only in ER). Based on this and other data described in more detail in our paper [39], we have concluded that apoptotic cells produce two distinct types of ACMV: 1) those derived from PM and possessing sialidase activity and desialylated, galactose-rich glycoepitops, and 2) those arising from ER and bearing oligomannose resides, residual components and glycolipids of ER-membranes, but lacking sialidase activity. These pathways are summarized in Fig. 4.

In our studies devoted to altered surface glycoprofile at apoptosis, we used apoptosis inducers of different nature: chemical (cisplatin, doxorubicun, etoposide, methothrexate, dexamethasone, etc.), physical (hyperthermia, X-radiation), and biological (anti-CD95-Ab, galectin-3). Both in vitro (a list of murine and human cell lines) and in vivo (human lymphocytes, PMN cells, mouse
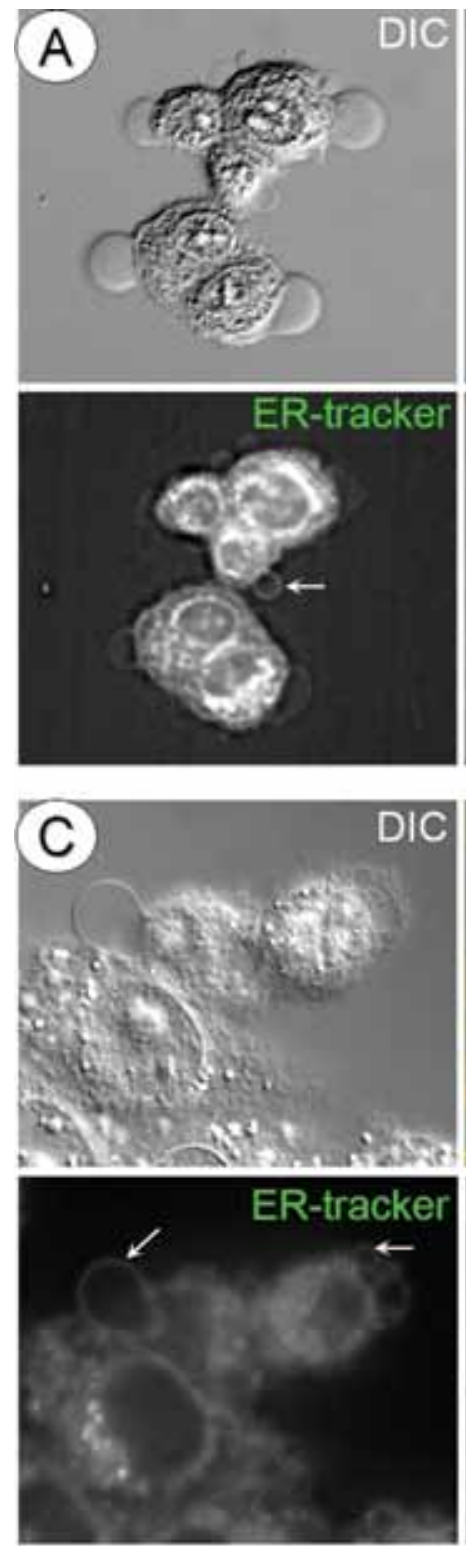
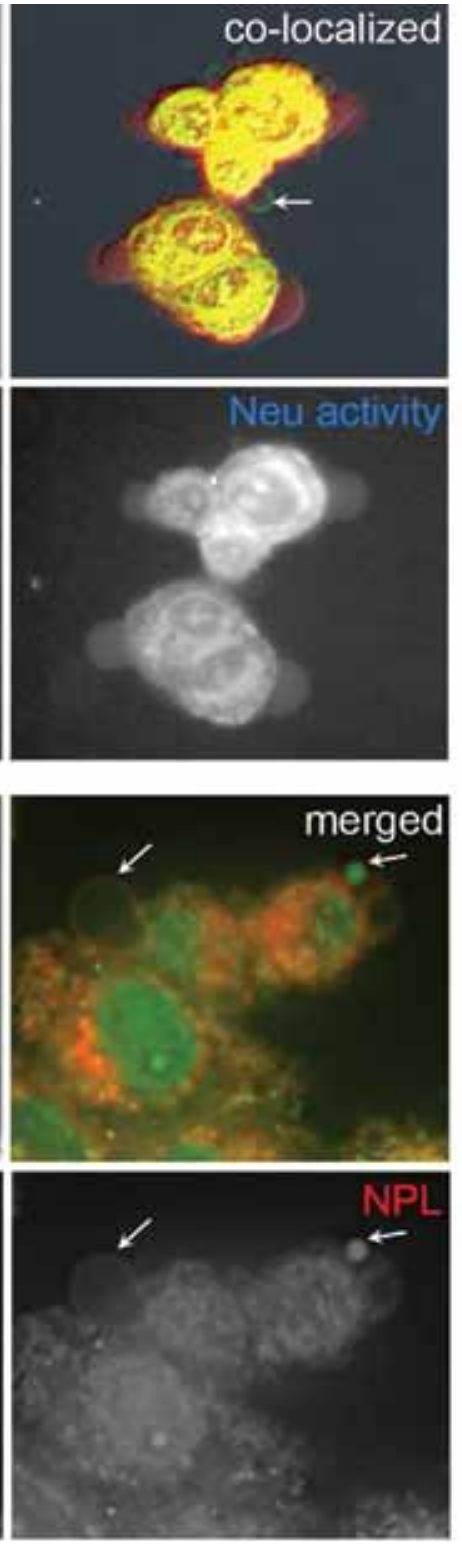
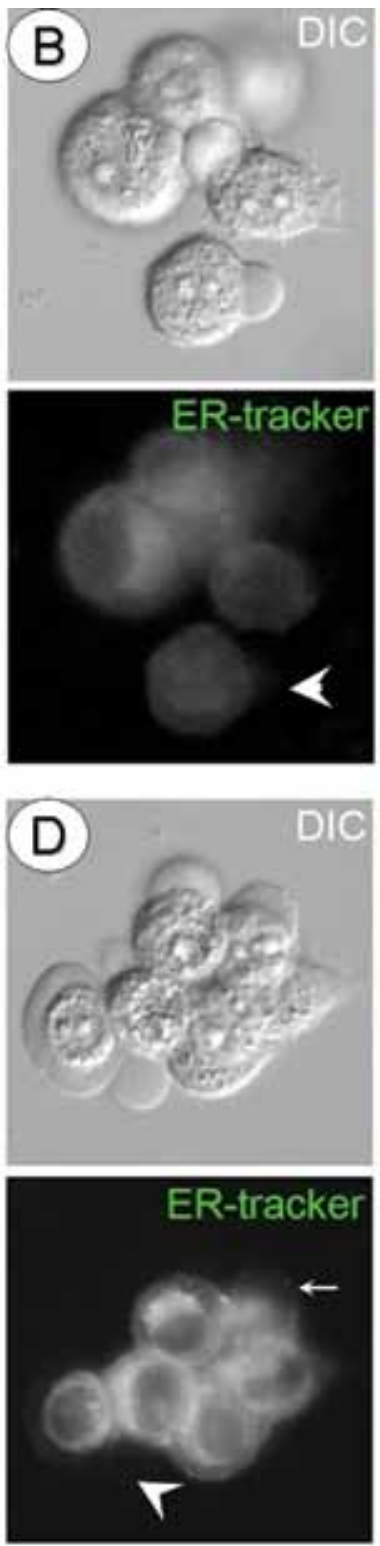
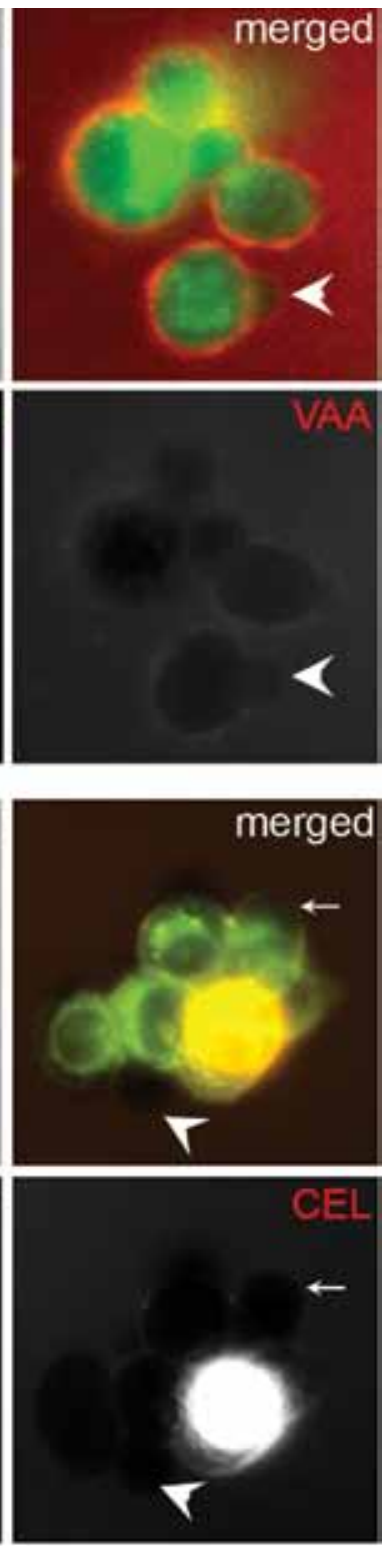

Fig. 3. Co-localization of ER-derived blebs with sialidase activity (negative, in A), VAA lectin staining (negative, in B), NPL lectin staining (positive, in $\mathrm{C}$ ) and CEL lectin staining (positive in D) 


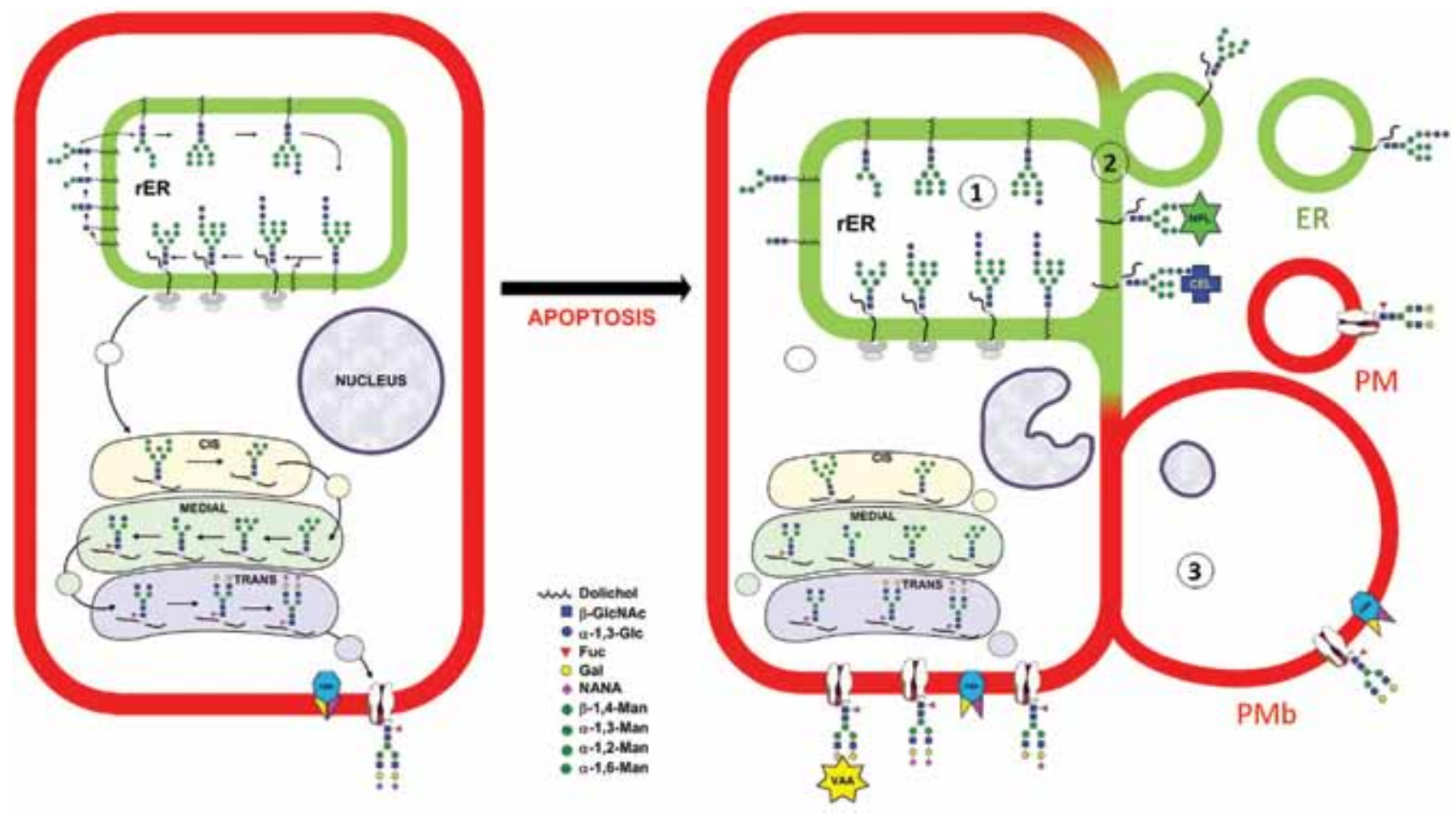

Fig. 4. The dual pathway model of altered $N$-glycan exposure during late apoptosis and formation of 2 distinct types of membrane blebs. (1) Conventional de novo glycan synthesis in not active during apoptosis. (2) ER membranes with immature glycans are exposed on cell surface and in the ER-derived blebs. (3) Apoptosis is accompanied by (caspase dependent, see later) activation of surface sialidases leading to desialylation of preexisting glycoepitopes on cell surface and PM-derived blebs which also can bear fragments of cell nucleus

splenocytes, murine L1210 leucocytes inoculated to mouse) grown cells were studied (26,30). Changes in cell PM glycoepitops were detected with peroxidase-labeled specific lectins with subsequent cytochemical analysis and of FITC-labeled lectins followed by flow cytometry. They were observed as early as 9-12 hrs after apoptosis induction (26), coinciding with the data of other investigators (25), and indicating that change of glycoepitops is an early feature of apoptotic cells.

Other data were obtained demonstrating that caspase cascade was the first common denominator in a series of molecular targets activated at apoptosis induction. We have analyzed in silico a sequence of 4 known human sialidases for their homology, presence of caspase cleavage sites, and availability of trans-membrane domains (Fig. 5A). The site of cleavage by caspase 3 was found to be present in human Neul with very high probability, as well as the trans-membrane domain. Then we screened the lysates of intact, caspase- 3 treated and aged human PMN cells for the expression of all known sialidases (Neu1-Neu4) by the Westernblot analysis (Fig. 5B). Human PMN cells served as a perfect experimental model, since at ageing these cells produce almost apoptotic cells which tend to maintain cell integrity with the absence of necrotic cells. For example, ageing for $24 \mathrm{~h}$ produced $\sim 50 \% \mathrm{AnV}^{-} / \mathrm{PI}^{-}$cells, $\sim 50 \% \mathrm{AnV}^{+} / \mathrm{PI}^{-}$cells, and less then $0.5 \%$ of $\mathrm{PI}^{+}$cells. Western-blot analysis revealed a marked decrease in Neul quantity upon treatment with the recombinant caspase 3 , as well as the cleavage of Neul (judged by changed MW). No changes in quantities, nor potential changes in MW of other sialidases, Neu2-Neu4, were found. We also showed [39] that pan-caspase and specific caspase inhibitors (towards caspases $3,7,8)$ blocked the sialidase activity observed in lysates and cell suspensions of the apoptotic human PMN cells. An increase in sialidase activity was blocked by immunoprecipitation with anti-Neul antibodies, and in MCF-7cell line lacking caspase-3 expression. However, knock-in of MCF-7 cells with caspase- 3 gene resulted in the increase of sialidase activity at apoptosis [39]. These and other data presented in [39] allowed us to suggest a specific molecular mechanism leading to caspase-3 dependent cleavage, membrane translocation and 


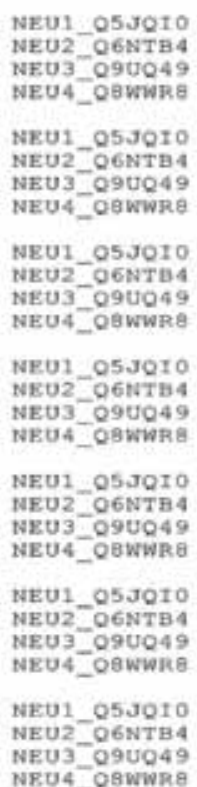

B

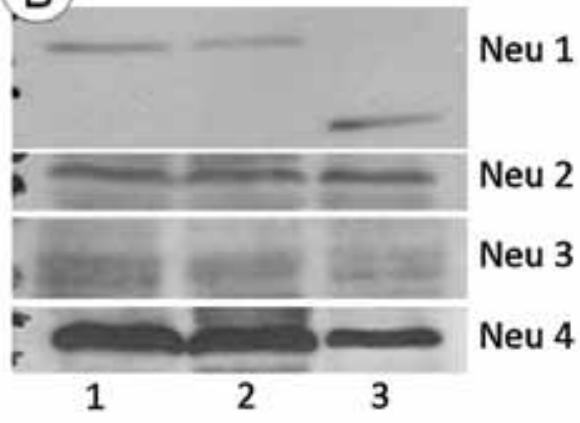

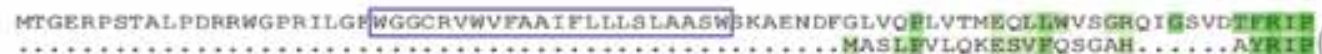

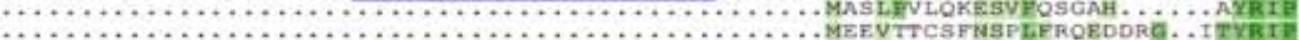

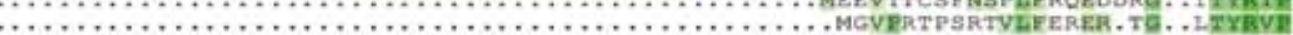

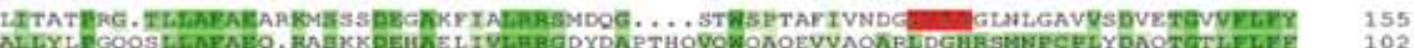

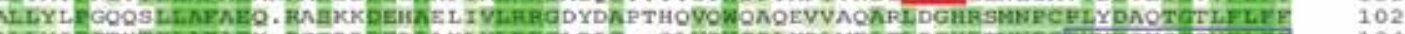

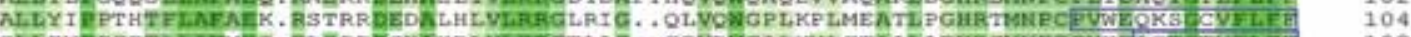

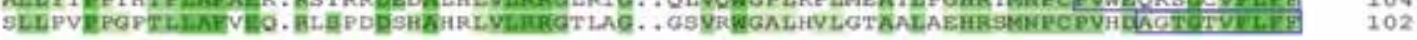

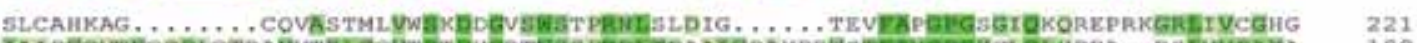

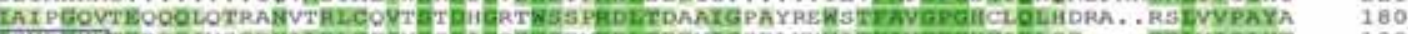
ICVACHVTERO IVSGPWAARICFr Y

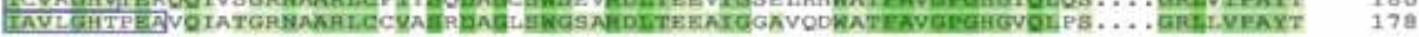

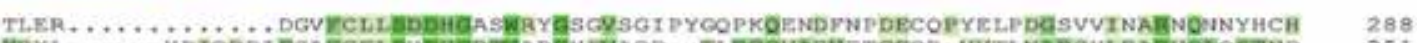

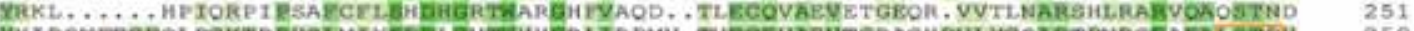

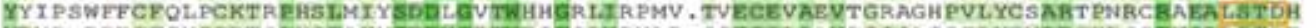

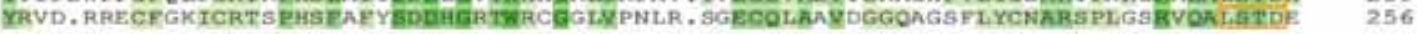

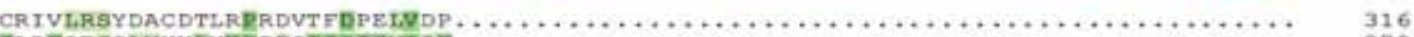

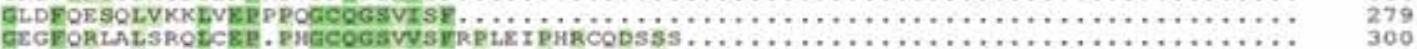

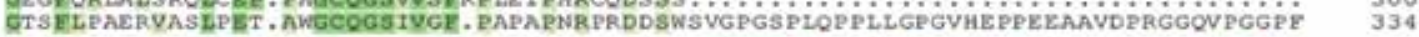

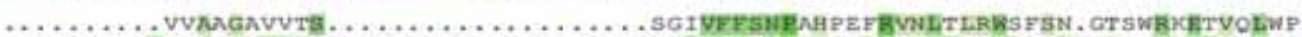

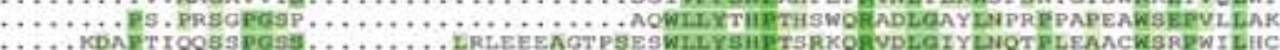
BRLQPRGDGPROPGPREG

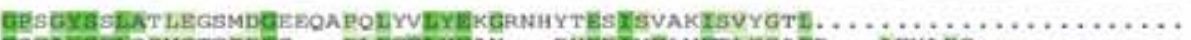

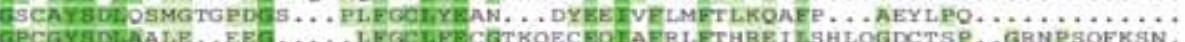

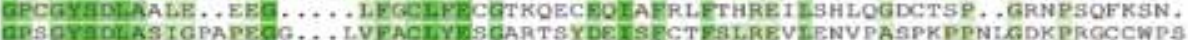

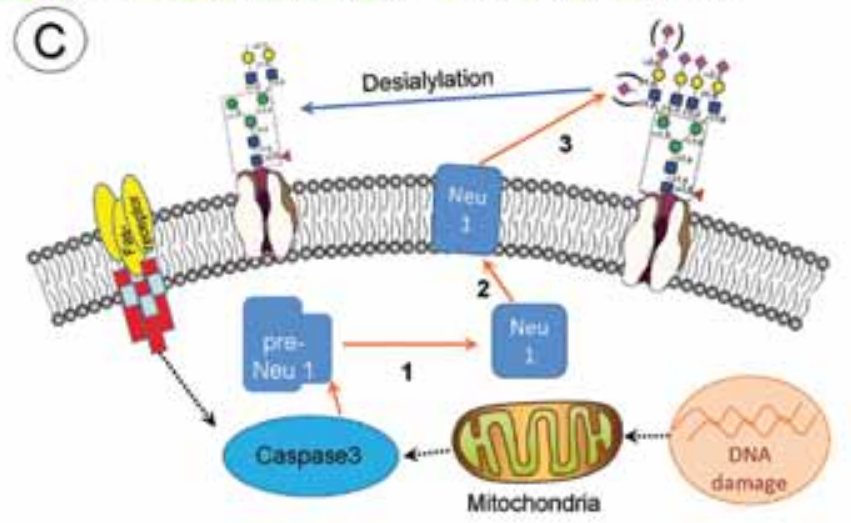

Fig. 5. A - Alignment of amino acid sequence of 4 known human sialidases (Neu1-Neu4) with protein codes indicated in the left. Amino-acid homology is represented by a shade of green. Red - predicted cleavage site for caspase 3 (Score 12, estimated by GrabCas), orange - predicted cleavage site for caspase 8 (Score 4.5, estimated by GrabCas), blue - trans-membrane domains predicted with HMMTOP and TMHMM. Caspase cleavage sites have been verified with GrabCas, CASVM, PeptideCutter, and CasCleave. B - Western-blot analysis of expression of sialidases in human peripheral blood granulocytes', 1 - intact cells, 2 - intact cells treated with recombinant caspase 3, 3 - apoptotic (aged) cells. $C$-Schematic representation of events which lead to activation of sialidase Neu1 at apoptosis: 1 - cleavage with caspase 3, 2 - translocation to the PM, 3 - desialylation of surface glycoepitops

exposure of cell surface sialidase activity at apoptosis (Fig. 5C).

Altered glycoepitops at cell clearance and autoimmune disorders

Inappropriate clearance of dying cells and their remnants (apoptotic blebs and apoptotic bodies) lead to accumulation of dying cells remnants modified by the oxidative process, and, thus, immunologically "foreign" for the organism [54]. Cells eventually loose their integrity and release modified apoptotic cell content to milieu that pro- vokes immune response [55-57]. Chronic failure of apoptotic cell clearance is now widely accepted to be a primary cause which initiates systemic autoimmunity in diseases such as systemic lupus erythematosus (SLE) [58, 59].

There are two distinct types of ACMV produced at apoptosis [39]: a) those derived from plasma membrane (PM), and characterized by increased sialidase activity, desialylated glycoprofile, exposing PS and being usually quite big (from 1 to up to $25 \mu \mathrm{m}$ ), produced in a range of one to few per cell, and b) those derived from en- 
doplasmic reticulum (ER), possessing immature oligomannose-rich glycans typical to ER, usually being produced much smaller in size $(\sim 2-5 \mu \mathrm{m})$ but in higher numbers, and reportedly exposing other ER components, such as calnexin, KDEL receptor [51], and calreticulin [60]. The latter type of blebs is preferentially engulfed by human macrophages, as shown by us [39], and the speed of phagocytosis was found to be independent on blebs' size, but dependent on their surface composition.

It is generally accepted that sialylation level is a basic mechanism regulating $\mathrm{RBC}$ clearance in the liver by Kupfer cells. However, it remains unknown whether this is also true for the apoptotic cells and can be used to facilitate their removal from the body. We analyzed whether desialylation influenced a process of apoptotic cell engulfment. To reach this aim, neuraminidase treated apoptotic cells and cell-derived membrane blebs were co-incubated with monocyte-derived phagocytes (both human blood derived and differentiated from monocyte progenitor cell line THP-1). Neuraminidase treated apoptotic cells and apoptotic blebs were washed before co-incubation (in the presence of heat inactivated fetal bovine serum) in order to remove residual neuraminidase. An engulfment of apoptotic cells and apoptotic cell-derived membrane blebs was quantified by flow cytometry. As shown in Fig. 6A, the engulfment of apoptotic cells was enhanced after neuraminidase treatment when compared to untreated cells. That effect was statistically significant if neuraminidase treatment was performed for $30 \mathrm{~min}$. At the same time, treatment of cells with sialidase inhibitor (DANA) abrogated the effect. Similar effect was observed at analyzing the engulfment of neuraminidase treated apoptotic cell-derived membrane blebs, as described by us [61]. To discriminate between binding of apoptotic cells and actual engulfment, we performed confocal microscopy, as shown in Fig. 6B. Here, almost every prey pre-treated with the neuraminidase was engulfed by phagocytes after co-incubation period.

Various constituents of the glycocalyx are recognised by a group of sugar binding proteins called the lectins [5]. Human lectins are divided into different groups depending on their structural diversities. C-Type-lectins (e.g. Mannose binding lectin, pulmonary surfactant, Macrophage mannose receptor, DC-SIGN) bind their ligands in a calcium-dependent manner. Galectins are specific for $\beta$-galactosides. I-type-lectins, which belong to the family of immunoglobulins, include the sialic acid specific group of siglecs [62]. These lectins are amongst others involved in pathogen recognition, complement activation, immunomodulation, cell adhesion, and migration [63]. CD43 and the asialoglycoprotein receptor were also involved in glycan recognition and phagocytosis [25]. Many other molecules involved in the recognition of "eat-me" signals on apoptotic cells, of both lipid, carbohydrate, protein and other nature, are perfectly described in recent paper published by Wei Li [26] (Fig. 7A).

To estimate whether there is a cooperativity between PS, oligomannose- and desialylated (galactose-rich) glycoepitops on dying cells in the ensuring their phagocytosis by macrophages (efferocytosis - phagocytosis of apoptotic cells), we used human monocytosis model which was described previously [39, 61]. Here, human venous blood-derived monocytes were differentiated into macrophages and syngenic (from the same donor) PMN cells aged for 24 hours served as an apoptotic prey. Prey cells were co-incubated with phagocytes (in $5: 1$ ration) for 2 hours, and the amount of uneaten cells was calculated. At the first stage, we tested a set of mannose-based derivatives and found that among many synthetic and natural compounds, heptyl- $\alpha$-D-mannoside possessed the most profound effect on the efferocytosis. That compound was synthesized by our colleagues Dr. S. Gouin and J. Bouckaert [64], and kindly provided for our experiments. Preliminary screening showed that galactose residues were perfectly blocked by galactose-specific human galectin 3 which was kindly provided by prof. H.-J. Gabius who is considered to be a "godfather" of the galectin science [65]. PS interaction were inhibited with annexin V [25]. Taking into account a suggestion described in [26], that desialylation might expose sub-terminal fucose residue which is being quite rare and can serve as a binding target for phagocytosis receptors, fucose was also included in the list of tested inhibitors. Schematically, the types of inhibition tested in the experiment are shown in Fig. 7B. The obtained data suggest that the engulfment of the apoptotic prey involves an interaction of three and more ligand-receptor pairs with oligomannose and desialylated glycans which are recognized by distinct mechanisms, as well as PS, and cooperation of all these three "eat-me" molecules is needed for normal efferocytosis. Since, even with using a combination of four inhibitors we were able to block efferocytosis by only $50-55 \%$, the involvement of other ligand-receptor pairs in the process should be assumed.

Contribution of $A C M V$ in development of autoantibodies. It is know that clearance-related diseases, like SLE, are accompanied by the presence of anti-DNA and anti-nuclear auto-antibodies, being a typical feature in $85-95 \%$ of cases [66], the etiology of this antibodies is unclear. When we first 
$\boldsymbol{A}$

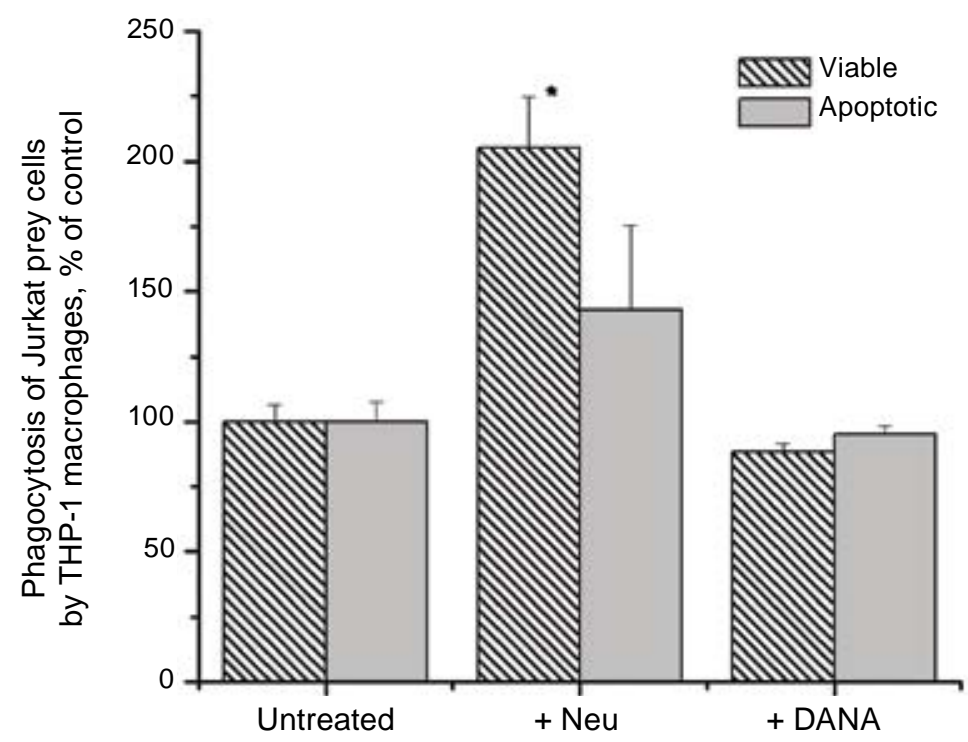

$B$

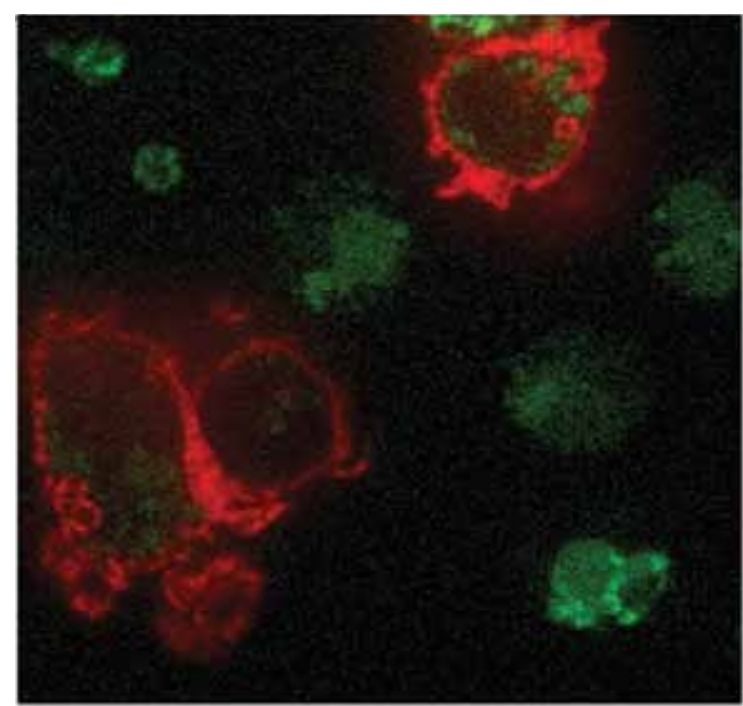

apoptotic cell untreated

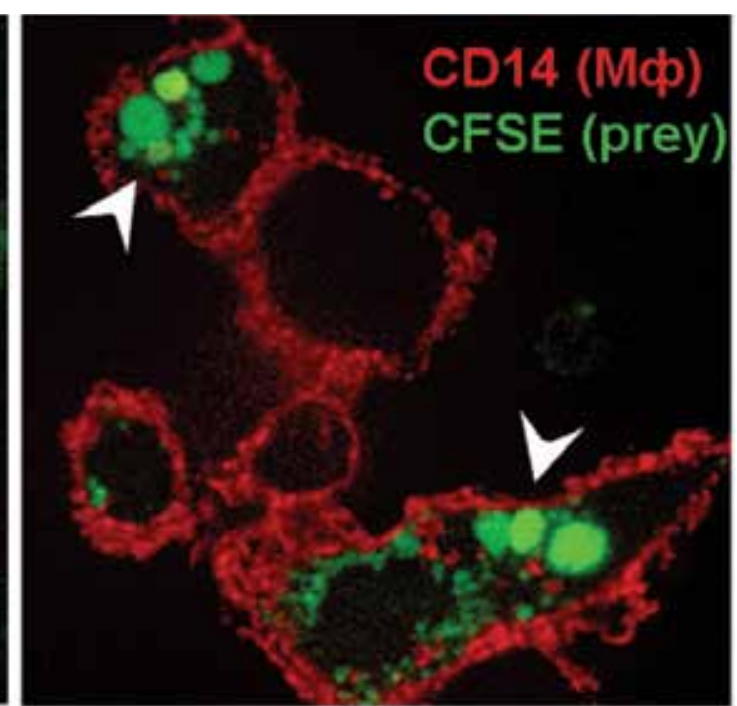

apoptotic cells Neu-treated

Fig. 6. Neuraminidase-treatment enhances uptake of apoptotic cells. A - THP-1 monocyte-derived phagocytes were co-incubated with CFSE-labelled apoptotic Jurkat T-cells. Numbers of phagocytes (CD14+) possessing CFSE signal (those, engulfed the preys) and normalized to controls are shown. The graphs show mean values $\pm S D$ of 3 independent experiments. $\boldsymbol{B}$ - Confocal microscopy of anti-CD14 stained phagocytes (red) and CFSE stained apoptotic cells (green) is shown. Left: untreated lymphoblasts; right: lymphoblasts after neuraminidase treatment for $30 \mathrm{~min}$. White arrow tips indicate the engulfed apoptotic cells. Reprinted with permission from [61]

demonstrated that some nuclear components, like histone $\mathrm{H} 2 \mathrm{~B}$, but not components of nuclear membrane [39], were exposed in ACMV, and taking into account that: a) ACMV are fragile and are more likely to release their content to milieu, and b) insufficient clearance results in a chronic inflammation [58] and production of auto-antibodies against self proteins, we searched for nuclear components in ACMV.
We used human HeLa cells stably expressing histone H2B-GFP, and induced their apoptosis with UV-B irradiation. We applied differential interference contrast (DIC) to visualize apoptotic blebs and observed that after 4 to 6 hours, cells started to produce a blebbing pattern typical to this and many other cell types: up to few dozens per cell of relatively small $(0.5-5 \mu \mathrm{m}) \mathrm{ACMV}$ and lately one or rarely two big ACMV which we desig- 

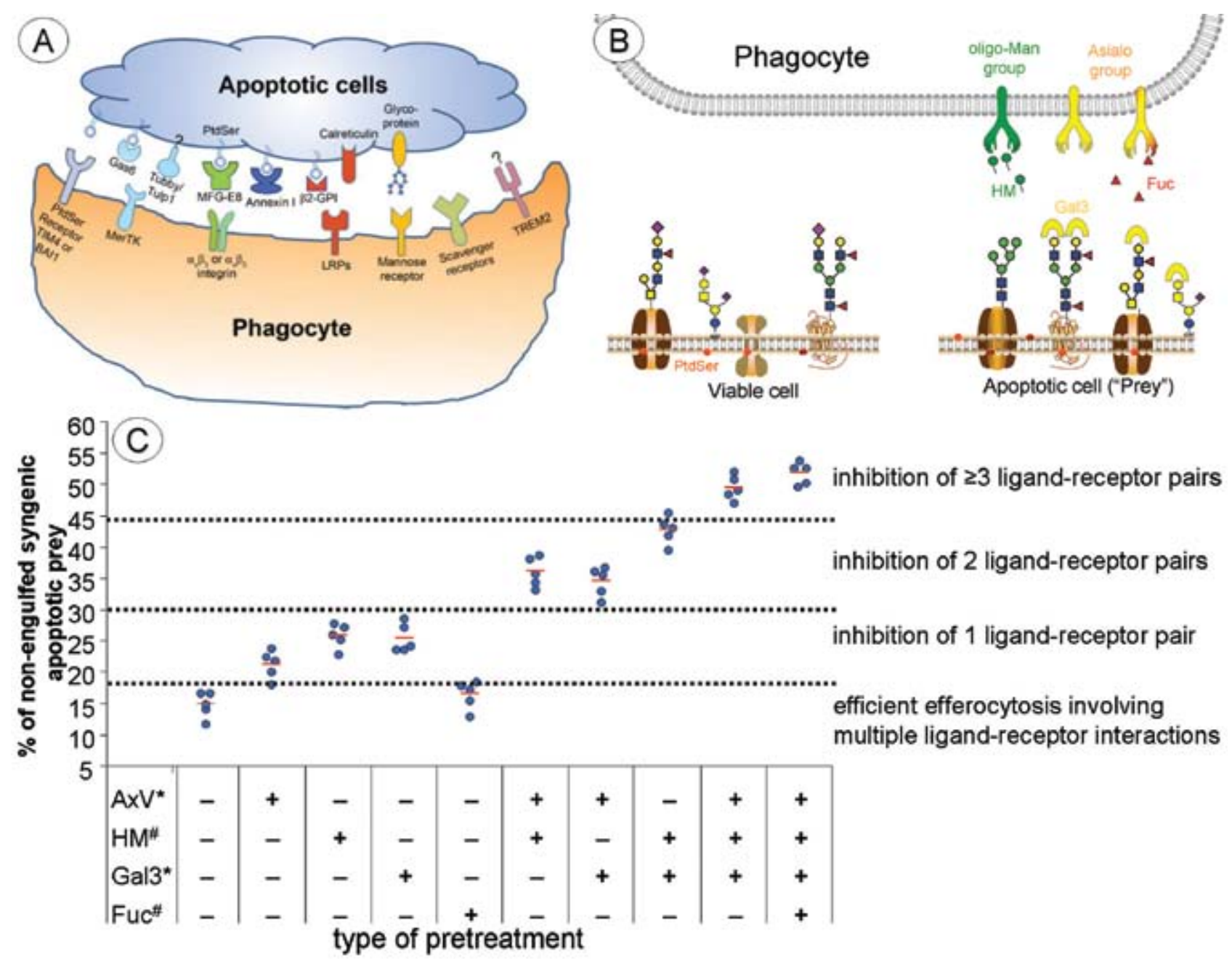

Fig. 7. A - Eat-me signals and phagocytic receptors for the engulfment of apoptotic cells. The apoptotic cells display various eat-me signals, which bind to their receptors on phagocyte surface either directly or indirectly through bridging molecules. Multiple eat-me signals and their receptors can form a cluster within the phagocytic cup as the engulfment synapse to facilitate the clearance of apoptotic cells. Eat-me signals and their cognate receptors are shown in the same color. Reprinted with a permission from [26]. B - Schematic representation of changes of glycoepitops on apoptotic cells and inhibition of potential glycans-receptor pairs involved in cell clearance. $\boldsymbol{C}-$ Engulfment of apoptotic prey involves interaction of three and more ligand-receptor pairs, with oligomannose and desialylated glycans being recognized by distinct mechanisms. Data on inhibition of efferocytosis using the indicated inhibitor pairs.

*-pretreatment of prey, \# - pretreatment of $M d$; AxV - annexin V, $200 \mu \mathrm{g} / \mathrm{ml} ; \mathrm{HM}$ - heptyl a-D-mannoside $10 \mathrm{nM}$; Gal3 - human Galectin3, $100 \mu \mathrm{g} / \mathrm{ml} ; \mathrm{Fuc}$ - fucose, $200 \mu \mathrm{g} / \mathrm{ml}$

nated as a "terminal bleb". Interestingly, some of the terminal blebs possessed nuclear material visualized as fluorescent histone H2B signal by using fluorescent microscopy, nuclear material being enclosed by plasma membrane visualized by DiIC $_{18}(3)$ (Invitrogen) staining (Fig. 8A). We also performed counterstaining of the apoptotic HeLa cells expressing histone H2B-GFP with DAPI, and demonstrated that the prevailing majority of terminal blebs possessing histone $\mathrm{H} 2 \mathrm{~B}$ were positive for DNA revealed by DAPI (Fig. 8B). Thus, some of the apoptotic ACMV, namely big terminal blebs, can contain nuclear material, namely DNA and histones of dying cells. Due to big size, these terminal blebs are most labile among the apoptotic remnants, they are derived from plasma membrane, as we have shown earlier the clearance of PM-derived blebs by the macrophages is relatively slow in comparison to ACMV derived from ER [39]. Due to high fragility, these terminal blebs have high chance to be damaged and leak internal content, DNA and histone, into cellular milieu in 

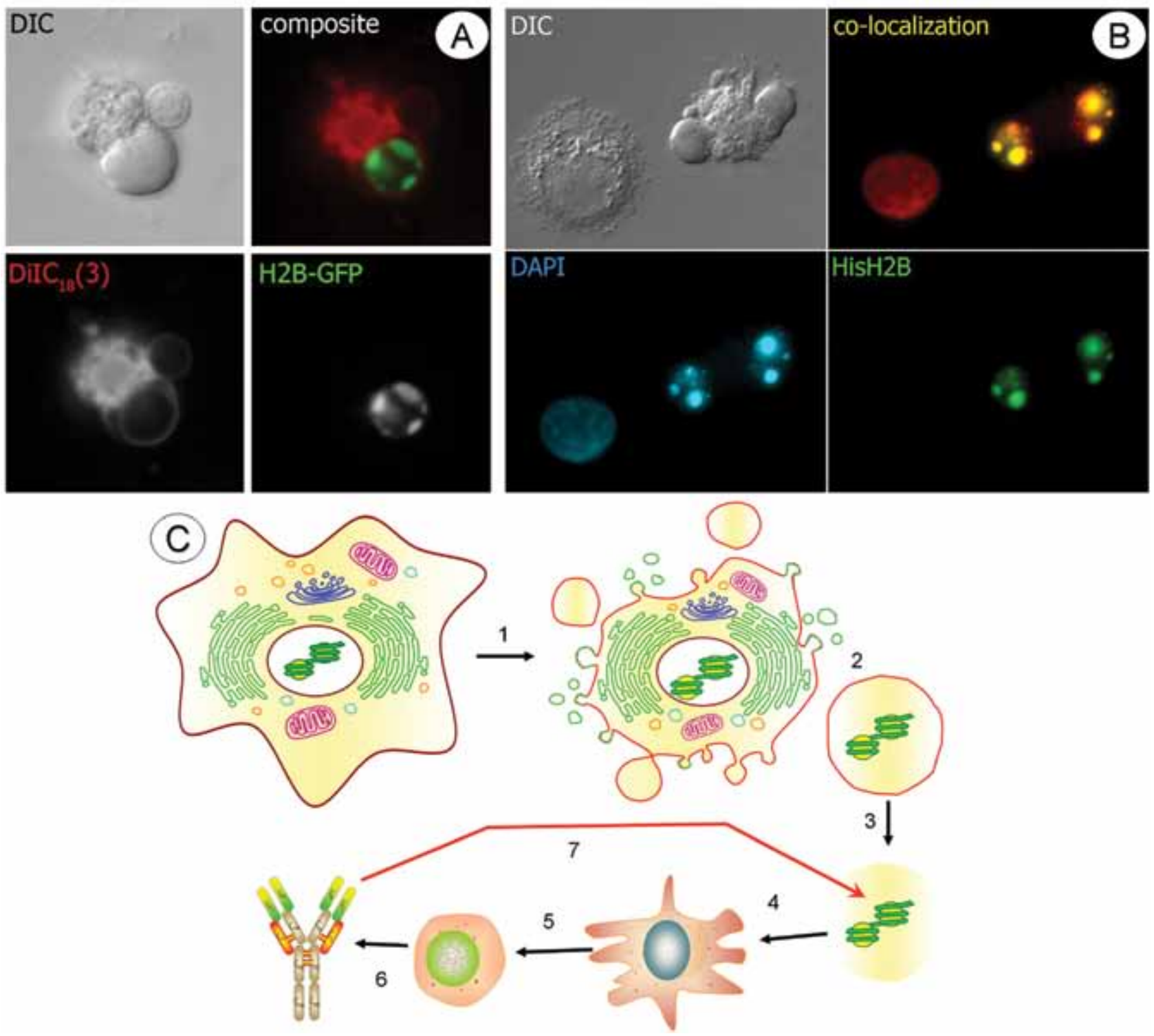

Fig. 8. A - Apoptotic (UV-B irradiated) HeLa cells produce big plasma membrane-derived ("terminal") $A C M V$ which can contain nuclear material, visualized by histone H2B-GFP signal. The plasma membrane was pre-stained the lipophilic dye DiIC ${ }_{18}(3)$. B - Terminal apoptotic ACMV can contain nuclear material as DNA (DAPI staining) and histones (histone H2B-GFP signal). In a co-localization image, the DAPI signal is pseudo-colored in red for better visualization. $C$ - Hypothetical scheme describing how the apoptotic events might lead to anti-nuclear auto-Ab production. During apoptosis (1) the cell exposes different types of the ACMV with terminal ACMV (2) possessing nuclear material. Inappropriate efferocytosis of these ACMV (3) leads to the leakage of their contents (3) into the extracellular milieu and their presentation to immune cells (4) results in immune response (5) and production of anti-nuclear auto-Ab (6). These antibodies then bind nuclear debris (7)

case of an inappropriate clearance or accidental damage.

Taking into account these data, we suggested that selective exposure of nuclear material in a big and fragile apoptotic ACMV can be a way of exposure of nuclear material into milieu, as well as a reason to cause a development of antibodies against the nuclear components (Fig. 8C). Recently, it was shown by Shiller et al. [67] that High mobility group box protein B1 (HMGB1), a nuclear protein reportedly involved in structural organization of DNA and usually released from the necrotic cells or upon cellular activation, is translocated into the ACMV at apoptosis, also in paper in press, further supporting a proposed hypothesis. 
Thus, carbohydrate recognition systems play a crucial role in detecting the apoptotic cells, as well as their clearance from the organism.

\section{Acknowledgements}

The authors wish to thank those who contributed greatly in different stages of this work, particularly Tanya Dumych (Shkandina), Andriy Tomin, Iryna Mahorivska, Christina Janko, Luis E. Muñoz, Iryna Kril, Yaroslav Tolstiak, Valentyna Chop'yak, Matthias Zirngibl, Barbara G. Fürnrohr, Martin Schiller, Petra Heyder, Marijo Parcina, Georg Schett, Maxim Lootsik, Hans-Joahhim Gabius. We are especially grateful to Martin Herrmann, Volodymyr Antonyuk, and Yuriy Ya. Kit.

\section{ЗАГИБЕЛЬ КЛІТИН МАЕ СОЛОДКИЙ ПРИСМАК: РОЛЬ ВУГЛЕВОДІВ У СИСТЕМІ РОЗПІЗНАВАННЯ}

\section{P. Білий, Р. Стойка}

Інститут біології клітини НАН України, Львів; e-mail: r.bilyy@nas.gov.ua; stoika@cellbiol.lviv.ua

У статті описано складний шлях, завдяки якому зміни глікоепітопів на поверхні відмираючих клітин дозволили виявити специфічні механізми, що лежать в основі реорганізації клітини за апоптозу. Ці глікоепітопи відіграють важливу роль у забезпеченні видалення фрагментів відмираючих клітин 3 організму, останні, у свою чергу, здатні спричиняти утворення автоантитіл.

К л ю ч о в і с л о в а: апоптоз, глікоепітопи, плазматична мембрана, мікровезикули, фагоцитоз.

\section{ГИБЕЛЬ КЛЕТОК ИМЕЕТ СЛАДКИЙ ПРИВКУС: РОЛЬ УГЛЕВОДОВ В СИСТЕМЕ РАСПОЗНАВАНИЯ}

\section{P. Билый, Р. Стойка}

Институт биологии клетки НАН Украины, Львов; e-mail: r.bilyy@nas.gov.ua; stoika@cellbiol.lviv.ua

В статье описан сложный путь, благодаря которому изменения гликоэпитопов на поверхности отмирающих клеток позволили обнаружить специфические механизмы, лежащие в основе реорганизации клетки при апоптозе. Эти гликоэпитопы играют важную роль в обеспечении удаления фрагментов отмирающих клеток из организма, последние, в свою очередь, способны вызывать образование аутоантител.

К л ю че в ы е с л о в а: апоптоз, гликоэпитопы, плазматическая мембрана, микровезикулы, фагоцитоз.

1. Lawen A. Apoptosis - an introduction // BioEssays. - 2003. - 25. - P. 888-896.

2. Fadok V. A., Voelker D. R., Campbell P. A. et al. // J. Immunol. - 1992. - 148. - P. 2207-2216.

3. Hochreiter-Hufford A., Ravichandran K. S. // Cold Spring Harb. Perspect. Biol. - 2013. - 5.

4. Gabius H. J., Siebert H. C., Andre S. et al. // Chembiochem. - 2004. - 5. - P. 740-764.

5. Sharon N., Lis H. // Glycobiology. - 2004. 14. - P. 53R-562.

6. Antonyuk $V$. O. The lectins and their resources [in Ukrainian]. - Lviv: Quart, 2005.

7. Pittoni V., Valesini G. // Autoimmun. Rev. 2002. - 1. - P. 154-161.

8. Geijtenbeek T. B., van Vliet S. J., Engering A. et al. // Annu. Rev.Immunol. - 2004. - 22. P. $33-54$.

9. Cline A. M., Radic M. Z. // Clin. Immunol. 2004. - 112. - P. 175-182.

10. Henson P. M., Bratton D. L., Fadok V. A. // Curr. Biol. - 2001. - 11. - P. R795-R805.

11. Fujita T., Matsushita M., Endo Y. // Immunol. Rev. - 2004. - 198. - P. 185-202.

12. Bilyy R., Stoika R. // Autoimmunity. - 2007. 40. - P. 249-253.

13. Kerr J. F., Wyllie A. H., Currie A. R. // Br. J. Cancer. - 1972. - 26. - P. 239-257.

14. Duvall E., Wyllie A. H., Morris R. G. // Immunology. - 1985. - 56. - P. 351-358.

15. Morris R. G., Hargreaves A. D., Duvall E., Wyllie A. H. // Am. J. Pathol. - 1984. - 115. P. $426-436$.

16. Dini L., Autuori F., Lentini A. et al. // FEBS Lett. - 1992. - 296. - P. 174-178.

17. Hall S. E., Savill J. S., Henson P. M., Haslett C. // J. Immunol. - 1994. - 153. - P. 3218-227.

18. Dini L., Lentini A., Diez G. D. et al. // J. Cell Sci. - 1995. - 108, Pt 3. - P. 967-973.

19. Falasca L., Bergamini A., Serafino A. et al. // Exp. Cell Res. - 1996. - 224. - P. 152-162.

20. Verhoven B., Krahling S., Schlegel R. A., Williamson P. // Cell Death. Differ. - 1999. 6. - P. 262-270.

21. Verhoven B., Schlegel R.A., Williamson P. // J. Exp. Med. - 1995. - 182. - P. 1597-1601.

22. Krahling S., Callahan M. K., Williamson P., Schlegel R. A. // Cell Death. Differ. - 1999. 6. - P. 183-189.

23. Reutelingsperger C. P., Christiaan Peter M. (inventors). Method for detecting and/or 
optionally quantifying and/or separating apoptotic cells in or from a sample. United States patent 5,834,196.

24. van den Eijnde S. M., Luijsterburg A. J., Boshart L. et al. // Cytometry. - 1997. - 29. P. 313-320.

25. Chaurio R. A., Janko C., Munoz L. E. et al. // Molecules. - 2009. - 14. - P. 4892-4914.

26. $L i W$. // J. Cell. Physiol. - 2012. - 227. P. 1291-1297.

27. Frey B., Munoz L. E., Pausch F. et al. // J. Cell Mol. Med. - 2008.

28. Munoz L. E., Frey B., Pausch F. et al. // Curr. Med. Chem. - 2007. - 14. - P. 271-277.

29. Rapoport E., Pendu J. L. // Glycobiology. 1999. - 9. - P. 1337-1345.

30. Bilyy R. O., Stoika R. S. // Cytometry A. 2003. - 56. - P. 89-95.

31. Heyder P., Gaipl U. S., Beyer T. D. et al. // Cytometry. - 2003. - 55A. - P. 86-93.

32. Bilyy R. O., Antonyuk V. O., Stoika R. S. // J. Mol. Histol. - 2004. - 35. - P. 829-838.

33. Azuma Y., Taniguchi A., Matsumoto K. // Glycoconj. J. - 2000. - 17. - P. 301-306.

34. Batisse C., Marquet J., Greffard A. et al. // Cytometry A. - 2004. - 62. - P. 81-88.

35. Bilyy R., Tomyn A., Stoika R. // J. Physiol. Sci. - 2009. - 59. - P. 155-155.

36. Franz S., Frey B., Sheriff A. et al. // Cytometry A. - 2006. - 69. - P. 230-239.

37. Bilyy R., Kit Y., Hellman U. et al. // Cell Biol. Int. - 2005. - 29. - P. 920-928.

38. Bilyy R., Kit Y., Hellman U., Stoika R. // Apoptosis. - 2008. - 13. - P. 729-732.

39. Bilyy R. O., Shkandina T., Tomin A. et al. // J. Biol. Chem. - 2012. - 287. - P. 496-503.

40. Miyagi T. // Proc. Jpn. Acad. Ser. B. - 2008. 84. - P. 407-418.

41. Achyuthan K. E., Achyuthan A. M. // Comp. Biochem. Physiol. B Biochem. Mol. Biol. 2001. - 129. - P. 29-64.

42. Nayak D. P., Reichl U. // J. Virol. Methods. 2004. - 122. - P. 9-15.

43. Tomin A., Shkandina T., Bilyy R. // Proc. SPIE, Clinical and Biomedical Spectroscopy and Imaging II. - 2011. - 8087. P. 80871Z-80871Z.

44. Bilyy R., Tomin A., Stoika R. (inventors). Method of neuraminidase activity detection in cells and cellular compartments. UA Patent No. 93816 patent.
45. Shkandina T., Herrmann M., Bilyy R. // Autoimmunity. - 2012. - 45. -P. 574-578.

46. Herscovics A., Orlean P. // FASEB J. - 1993. 7. - P. 540-550.

47. Kornfeld R., Kornfeld S. // Annu. Rev. Biochem. - 1985. - 54. - P. 631-664.

48. Helenius J., Aebi M. // Semin. Cell Dev. Biol. 2002. - 13. - P. 171-178.

49. Alaimo C., Catrein I., Morf L. et al. // EMBO J. - 2006. - 25. - P. 967-976.

50. Hubbard S. C., Ivatt R. J. // Annu.Rev. Biochem. - 1981. - 50. - P. 555-583.

51. Franz S., Herrmann K., Fuhrnrohr B. et al. // Cell Death. Differ. - 2007. - 14. - P. 733742.

52. Grieve A. G., Rabouille C. // Cold Spring Harb. Perspect. Biol. - 2011. - 3. - doi: 10.1101/ cshperspect.a005298.

53. Marie M., Sannerud R., Avsnes Dale H., Saraste J. // Cell. Mol. Life Sci. - 2008. 65. - P. 2859-2874.

54. Casciola-Rosen L. A., Anhalt G., Rosen A. // J. Exp. Med. - 1994. - 179. - P. 1317-1330.

55. Munoz L. E., Herrmann M., Gaipl U. S. // Z. Rheumatol. - 2005. - 64. - P. 370-376.

56. Michlewska S., McColl A., Rossi A. G. et al. // Autoimmunity. - 2007. - 40. - P. 267-273.

57. Schulze C., Sarter K., Herrmann M. // Autoimmunity. - 2007. - 40. - P. 239-243.

58. Munoz L. E., Lauber K., Schiller M. et al. // Nat. Rev. Rheumatol. - 2010. - 6. - P. 280289.

59. Gaipl U. S., Munoz L. E., Grossmayer G. et al. // J. Autoimmun. - 2007. - 28. - P. 114-121.

60. Obeid M., Tesniere A., Ghiringhelli F. et al. // Nat. Med. - 2007. - 13. - P. 54-61.

61. Meesmann H. M., Fehr E-M., Kierschke S. et al. // J. Cell Sci. - 2010. - 123. - P. 3347-3356.

62. Kottgen E., Reutter W., Tauber R. // Med. Klin. (Munich). - 2003. - 98. - P. 717-738.

63. Crocker P. R., Paulson J. C., Varki A. // Nat. Rev. Immunol. - 2007. - 7. - P. 255-266.

64. Gouin S. G., Wellens A., Bouckaert J., Kovensky J. // Chem. Med. Chem. - 2009. 4. - P. 749-755.

65. Beer A., Andre S., Kaltner H. et al. // Cytometry A. - 2008. - 73. - P. 139-147.

66. Pavlovic M., Kats A., Cavallo M. et al. // Autoimmune Diseases. - 2010. - 2010.

67. Schiller M., Heyder P., Ziegler S. et al. // Autoimmunity. - 2013. - 46. - P. 342-346. 